\title{
プロテアーゼ・インヒビター†
}

\author{
下 村 猛, 長池一博 \\ （三菱化成株式会社総合研究所）
}

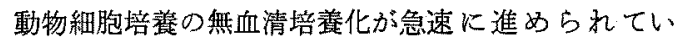
る. 現状で意識されている血清の役割は，主に EGF， PDGF，IGFs 等の増殖因子，またアルブミン，トラン スフェリン, LDL 等の環境因子の供給である(1). 一方, 付着依存性細胞をトリブシン等のプロテアーゼで剝離さ せた後，それらプャテフーゼの不活化を目的として血清 が使用されているが，培盖液中の血清のプロテフーゼ・ インヒビターとしての役割について言及されることは非 常に少ない。

ヒト血嶈中のプロテアーゼ・インヒビターの総量は, 血墏蛋白筫の約 10〜15\% に相当している (Table I) ${ }^{(2)}$. 細胞培盖に通常用いられるウシ胎児血清に拈いても， fetuin の存在のよ5に質や量的な相違はあっても，多種 多量のプロテアーゼ・インヒビターが存在し，塔峑細胞 に少なからぬ影響を与えていることは容易に想像される ことである.したがって，無血清培鹪時に和いては，他 の増殖因子や環境因子と同様にこれらプロテアーゼ・イ ンヒビターの役㓶についても考慮する必要がでてくる。

現在知られているプロテアーゼ・インヒビターの細胞 培養に対する機能的影響は下記の項目を上げることがで きる。

（1）細胞人の直接作用として, 細胞の增殖・生理的 機能を調節する增殖因子としての作用.

（2）細胞由来扎よび添加成分の調節等を通して間接 的に細胞に影響を及注す摆境因子としての作用。

（3）細胞の生産物および添加物質の培地中での分解 を抑制する生産物保護因子としての作用.

本稿においては，末ず增殖・環境因子としての側面か ら2〜3の例を記した後, 本ミニレビューのテーマに最 も関係する生産物保護因子としての役割の観点から述べ

\section{+ Protease Inhibitor.}

Takeshi SHIMOMURA and Kazuhiro NAGAIKE (Research Center, Mitsubishi Kasei Corporation, Midori-ku, Yokohama 227)

\section{ることにする。}

\section{1. 增殖 - 環境因子として}

環境因子として，培着細胞自身が多種類のプロテフー ゼを分必すること泉占，生た外部由来のプロテアーゼが 環境因子として働くことがすでに知られている。これら と同様 protease nexin 類(6)のようなオートクライン的な プロテアーゼ・インヒビターが，他のプロテアーゼ・イ ンヒどター ${ }^{(7 \sim 9)}$ の場合と同様に環境因子として作用して いることが, 最近, 数多く報告されている。 また, human embryonic lung cells の培盖系において，自己分泌した plasminogen activators (PAs)によって活性化された plasmin による細胞傷害性が，培峑液中に添加された血 清由来の fetuin で中和されていることが報告されてい $ろ^{(10)}$. fibroblast Kおける thrombin の作用化代表され るよらに,プロテアーゼが堌殖因子として働くこと(1) は 以前から知られていたが，最近になってブロテアーゼ・ インヒビターの一群である七リンプロテアーゼ・インヒ ビターが endothelial cells に対して特異的に㗢くこと(12) が，また逆に，glia-derived neurite promoting factor として報告されていた因子が，実は protease nexins 属するプロテフーゼ・インヒビターであること(13)等が 報告されている。この他，細胞培養においては数\%の死 細胞が通常存在し，そして、これら死細胞から漏出する ある種のプロテアーゼが細胞に対して何らかの作用を及 隹すことは当然予想される。

このよらに，通常の培盖下では，添加された血清と細 胞由来の複数のプロテアーぜとプロテアーゼ・インヒビ ターとが, その相互の特異性どうしバランスを保らつ つ, 細胞の增殖や生理的機能の発現に直接恋た間接的に 作用しているとみなせるだろう。

\section{2. 生産物保護因子として}

プロテアーゼ・インヒビターの他の因子と異なる掊㡺 に顿ける機能として，物質生産時に蛙ける生産物等の保 護因子としての役割があることが特筆される．先に述へ 
Table I. Protease Inhibitors in Human Plasma

\begin{tabular}{|c|c|c|c|}
\hline Protease inhibitors & $\begin{array}{c}\text { Molecular } \\
\text { weight }\end{array}$ & $\begin{array}{l}\mathrm{mg} / \mathrm{dl} \text { in } \\
\text { plasma }\end{array}$ & Proteases \\
\hline Alpha -antitrypsin & 53,000 & 250 & $\begin{array}{l}\text { Plasma kallikrein, thrombin, plasmin, elastase, } \\
\text { catepsin G. typsin, chymotrypsin, factor } \mathrm{Xa}\end{array}$ \\
\hline Antithrombin III & 55,000 & 29 & $\begin{array}{l}\text { Factor IXa, Xa, XIa, plasmin, thrombin, } \\
\text { plasma kallikrein }\end{array}$ \\
\hline Alpha $a_{2}$-antiplasmin & $65,000 \sim 70,000$ & 6 & $\begin{array}{l}\text { Plasmin, trypsin, plasma kallikrein, thrombin, } \\
\text { factor Xa, XIa, chymotrypsin }\end{array}$ \\
\hline Alpha ${ }_{1}$-antichy motrypsin & $58,000 \sim 68,000$ & 25 & Chymotrypsin, catepshin $\mathrm{G}$ \\
\hline $\mathrm{C}_{1}$-inhibitor & 104,000 & 17 & $\begin{array}{l}\text { CIr, C1s, factor XIa, XIIa, plasma } \\
\text { kallikrein, plasmin }\end{array}$ \\
\hline $\mathrm{Alpha}_{2}$-macroglobulin & 725,000 & 250 & $\begin{array}{l}\text { Thrombin, plasmin, plasma kallikrein, catepsin } \\
\text { B etc. }\end{array}$ \\
\hline Inter-alpha-trypsin inhibitor & 180,000 & $20 \sim 70$ & Plasmin, trypsin, chymotrypsin \\
\hline 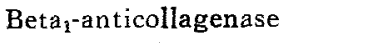 & $30,000 \sim 33,000$ & & Collagenase \\
\hline $\begin{array}{l}\text { Alpha }_{1} \text { thiolproteinase } \\
\text { inhibitor (HMW-KG) }\end{array}$ & 167,000 & & Catepsin H, L, B, papain \\
\hline $\begin{array}{l}\text { Alpha }{ }_{2} \text {-thiolproteinase } \\
\text { inhibitor (LMW-KG) }\end{array}$ & 50,000 & & Catepsin H, L, B, papain \\
\hline Heparin cofactor II & 72,000 & 9 & Thrombin \\
\hline Protein $\mathrm{Ca}$ inhibitor & 57,000 & 0.5 & Protein $\mathrm{Ca}$, factor $\mathrm{Va}$, VIIIa \\
\hline $\begin{array}{l}\text { Plasminogen activator } \\
\text { inhibitor } I\end{array}$ & 50,000 & $\begin{array}{r}0.01 \sim 1.3 \\
\text { nmol/liter) }\end{array}$ & $\mathrm{u}-\mathrm{PA}, \mathrm{t}-\mathrm{PA}$ \\
\hline
\end{tabular}

たように，培崶萑中には細胞の分泌ならびに死細胞から の漏出による種ふのブロテアーゼが存在し，それらプロ テァーゼによって生産物が培責液中で分解されることが 予想される，しかし，血清添加培養では，先に記したよ らに血清由来の多種多様のブロテアーゼ・インヒビター が存在して括り，それらプロテアーゼの活性は全体とし て抑制状態になっていると考元られる，一方，物質生産 においては，コストならびに後の精製を考慮した場合，

無血清堷埕化が当然必要とされる.この無血清培養飞お。 いていかにプロテアーゼ活性を抑制するか，すなから生 産物保護因子を供給するかは大きな問題である，細胞培 養にかかわる生産物保護因子はいかなる作用を要求され るのか，また，その対象となるプロテフーゼを検索する ことは容易ではない。

一般に，細胞抽出液中のプロテアーゼ活性注梌出され 難く，共存する内因性インヒビターを除去，または活性 化因子を添加して初めて活性が現れる．培養液中に漏出 するブロテフーゼも同様のことがい交，分泌型プロテア 一ビにおいても活性型・不活性型の両型が存在する。 た活性型であっても、リッソーム内プロテアーゼである カラ゙プシン群のように低 $\mathrm{pH}$ 儿至適 $\mathrm{pH}$ を持つるので は，通常の培皦条件とその至適条件の相堂等からその活
性が無視できる場合も考光られる，さらに，量的な問題 す㐫るだろら。

では，どのよらなプロテアーゼが培㝨夜中で活性を発 現しているか，われわれのデータを含め，現状ではまだ 数少ないいくつかの報告を, プロテフーせ・インヒビタ 一との関漣加ら紹介する。

K. Dano 5は ${ }^{(14)}$ ，[3H]DFP を用いて䣼菜との安定な 複合体を形成し，SDS-PAGE 後オートラジオグラフィ 一で挨出するという方法を用い, 正常 mouse embryo cells と sarcoma virus によるトランスフォーマントの 培羡液中の七リンブロデーゼとェステラーゼの樻出を 行っている.この実験により,トランスフォーマントで は 12 パンドを, 正常細胞では 9 バンドが榷認され，主 要なプロテフーゼがPAs であることが見出されている.

Bovine endothelial cells tissue type の PAs を無血清培盖で産生させた場合, $\mathrm{t}$ PAs の single chain $と$ u-PAs の $47 \mathrm{~K}, 58 \mathrm{~K} ヒ ゚ ー ク$ 以外低分子の $35 \mathrm{~K}, 28 \mathrm{~K}, 10 \sim 20 \mathrm{~K}$ のピークに活性 が検出される.この無血清培地にウシ脺䁍由来のプロテ アーゼ・インヒビターである Trasylol(aprotinin)を添加 することにより，低分子のピークの消失と高分子のピー クの增大が確認されている(Fig. 1) ${ }^{(15)}$.す格わち，apro- 
tinin によって阻害を受ける細胞由来プロテアーゼによ って, PAs が培養液中で分解を受けていたことになる. 哃様に, 組換え t-PA に関しても, aprotinin の添加で plasmin 様プロテアーゼによる single-chain t-PA の

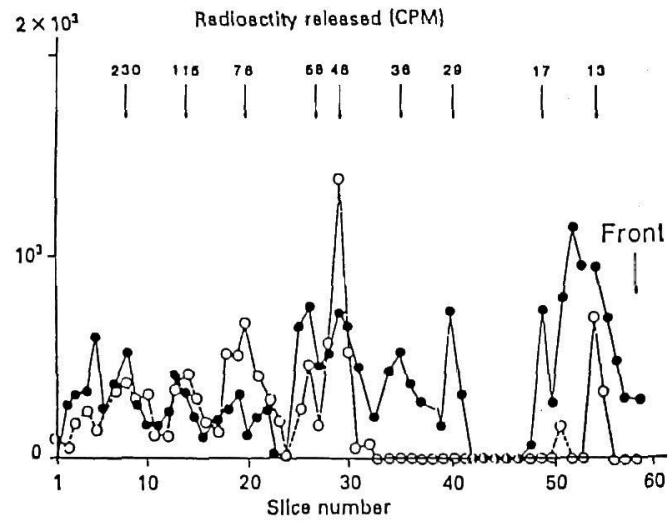

Fig. 1. Gelelectrophoretic Analysis of Serumfree, Concentrated Medium Conditioned by $\mathrm{BEC}$ in the Presence $(\mathrm{O} \cdots \mathrm{O})$ or Absence $(\cdots \bullet)$ of Trasylol. Results are expressed in radioactivity released by $1 \mathrm{~mm}$ slices (cpm/slice) incubated for $5 \mathrm{hr}$ on ${ }^{125} \mathrm{I}$-fibrin coated dishes in the presence of $4 \mu \mathrm{g}$ human plasminogen.

( A )

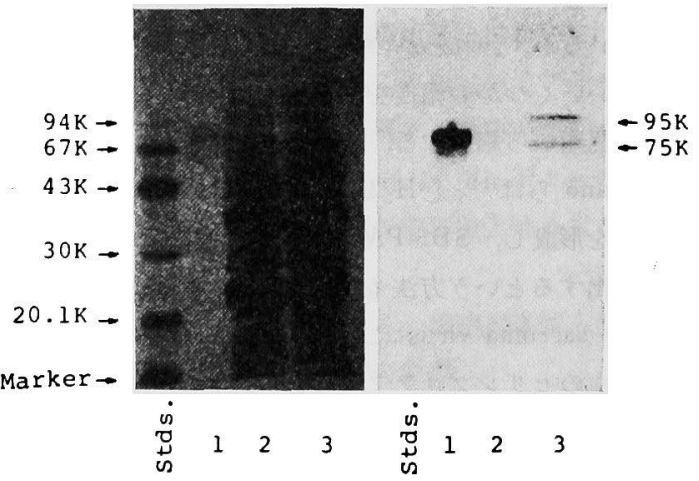

Fig. 2. Detection of Protease-Protease Inhibitor Complex in CHO Cells Culture Media. Western blotting analysis was performed after reduced SDS-PAGE, followed by amido black stain (A) or EIA stain with 5B6-3 MoAbs (B), which were anti-FBS-derived inhibitor with C1-inhibitor like activity mouse IgG. Lane 1 represents FBS-derived inhibitor with C1-inhibitor-like activity. Lanes 2 and 3 represent culture media without and with that inhibitor. $75 \mathrm{~K}$ and $95 \mathrm{~K}$ arrows indicate protease inhibitor and proteaseprotease inhibitor complex, respectively. two-chain t-PA への変化が培責液中で抑制されること が知られている. また，aprotinin に関しては，無血清 培養時に添加された insulin p substance P の分解を 痋らせるとの報告等もあり，培養への添加物として，す でにパルクで供給されている.

Human oestrogen receptor 遺伝子が導入された $\mathrm{HeLa}$ cells の培盖液中には, intact な $65 \mathrm{~K}$ 分子以外 に $45 \mathrm{~K}$ の低分子バンドが認められているが,これは 分泌後の分解による産物であるだろらと報告されてい

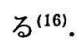

分泌される蛋白質とは異なるが， BHK cells で Rabies virus を増殖させた場合, BHK cells の細胞膜上の プロテフーゼによってゥイルスの膜糖蛋白質が分解さ れスパイクレス粒子が産生されることが報告されてい る.たた゚し，この場合は培屓液の $\mathrm{pH}$ を 7.0 以上に保 つことにより対応ができ，この分解が抑制されることが すでに見出されている(17).

筆者たちは，一般に広く用いられている遺伝子組換总 のホスト細胞である $\mathrm{CHO} \cdot \mathrm{dhfr}^{-} を$ 用いた組換え体の培 養液中に, 一つのプロテフーゼが多量に活性型で存在 することを見出した. このプロテアーゼは，ウシ胎児血 清由来の C 1-inhibitor 様活性を持つプロテアーゼ・イ ンヒビターにより培養条件下で特異的に阻害され，還元 条件下 SDS-PAGEに拈いても安定な複合体を形成する ことを確認した (Fig.2). 本プロテアーゼの特異性に ついて，同様の方法で検索を行ったところ， $\alpha_{1}$-antitrypsin, $\alpha_{2}$-antiplasmin, antithrombin III は高濃度であ 複合体形成は認められず, ヒト由来 C1-inhibitor のみ 同様な複合体が認められた.ささに，無血清培地中で分 解していた組換觉体産物は，プロテアーゼに対する阻害 スペクトルが幾分異なるこれら 2 つのヒト由来とウシ胎 児由来 C 1-inhibitor 様インヒビターの一方を添加する ことで，その分解が抑制されたことより，これら2種の インヒビターが複合体を形成したプロテアーゼは同一物 質たと確認された。このプロテアーゼは類似したスぺク トルを示す CHO cells が分泌しているという t-PA と は異なったものであること，他にホストとして用いた BHK cells には多量には存在しないことが証明されてい る.

他の生体由来ならびに合成プロテアーゼ・インヒビタ 一の使用の可能性を検討する目的で, 約 20 種類につい て本プロテアーゼに対する阻害活性と細胞毒性をアッセ 
イしたところ，PAsの分解を抑制した aprotinin は無 效であり，セリンプロテフーゼに対して幅広い阻害活性 を持つ DFP, PMSF 等は，その阻害活性より細胞毒性 が強く培着には不適であった。唯一、メシル酸ナフっモ スタットに有效性が認められたが，1週間以上の長期培 養では細胞傷害性が現れ問題があった。

以上の報告とわれわれが得た結果は，次の 2 点敒集約 される.一つは，実際に問題となるプロテアーゼは，個

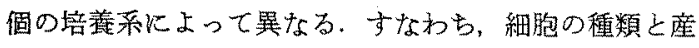
生物質ならびに培盖条件の組合せにより，必要とされる ブロテアーゼ・インヒビター活性が異なる，そしてるら

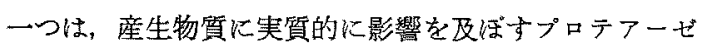
は1〜2種類であり，通常の培養条件下では無制限な分 解は起こり難い。ゆえに，培着に添加されるべきプロテ アーゼ・インヒビターは 1 ～ 2 種類でよい，また，それ らプロテアーゼ・インヒビターには次のような性質が望 まれる、高力価である、細胞毒性が低く，培着条件上問 題を生じない.マイナーなプロテアーゼをる考虑した場 合には，阻害スペクトルが広い，低価格である，そし て；実際には個々の培養条件で詳細に检討される必要が ある. 安た，長期培盖に拉いて，とくに合成のプロテア 一ビ・インヒビターを用いる場合は，その力伍々毒性の バランスが重要な課題となる.

(1) D. Barnes and G. Sato: Cell, 22, 649 (1980)

(2) J. Travis and G.S. Salvesen: Annu. Rev. Biochem., 52, 655 (1983).
(3) J.S. Molt, A.D. Recklies and A.R. Poole: Biochim. Biophys. Acta, 614, 134 (1980).

(4) M. Grofova, E. Larsson, A. Bengtsson, J. Bizik, B. Westermark and J.Ponten : In Vitro Cell. Develop. Biol., 24, 369 (1988).

(5) G.P. Stricklin, A. Z. Eisen, E. A. Bauer and A. J. Jeffrey : Biochemistry, 17, 2331(1978).

(6) D. J. Knauer, J.A. Thompson and D. D. Cunningham: $J$, Cell. Physiol., 117, 385 (1983).

(7) R. P. Gupta, S. E. Patton, A.M. Jetten and G. E. R. Hook : Biochem. I., 248, 337(1987).

(8) J.A. van Mouric, D. A. Lawrence and D. J. Loskutoff : J. Biol. Chem., 259, 14914 (1984).

(9) G.P.Stricklin and H.G. Welgus : J. Biol. Chem., 258, 12252 (1983).

(10) S.T.Rohrlich and D.B. Rifkin : J. Cell. Physiol., 109, 1 (1981).

(11) B. R. Zetter, T.Sun, L. B. Chen and J.M. Buchanan : J. Cell. Physiol., 92, 233 (1977).

(12) W. L. McKeehan, Y. Sakagami, H. Hoshï and K. A. McKeehan : J. Biol. Chem., 261, 5378 (1986).

(13) A.Gloor, K. Odink, J. Guenther, H. Nick and D. Monard : Cell, 47, 687 (1986).

(14) K. Dano and E. Reich : J. Exp. Med., 147, 745 (1978).

(15) W.E. Laug: Thromb. Haemostasis, 50, 88 (1983).

(16) S.Green, P. Walter, V. Kumar, A. Krust, J. M. Bornert, P.Argos and P. Chambon: Nature, 320, 134 (1986).

(17) A. Kawai and S. Matsumoto : Virology, 108, 267 (1981). 